\title{
PENGARUH INFLASI, NILAI TUKAR RUPIAH, BI RATE TERHADAP NET ASSET VALUE REKSA DANA
} SAHAM SYARIAH ${ }^{11}$

\author{
Ainur Rachman \\ Mahasiswa Program Studi S1Ekonomi Islam - Fakultas Ekonomi dan Bisnis-Universitas Airlangga \\ Email: ainur_r17@yahoo.co.id \\ Imron Mawardi \\ Departemen Ekonomi Syariah - Fakultas Ekonomi dan Bisnis - Universitas Airlangga \\ Email: ronmawardi@gmail.com
}

\begin{abstract}
:
This research aims to examine the influence of inflation, Rupiah exchange rate, and Bl rate towards Net Asset Value (NAV) Sharia Equity Fund from January 2011 through December 2014. This research used the quantitative approach method. The analysis techniques used is multiple linear regression and the equation is $Y=12,081-1,755$ (I)-0, 131 (RER)-84,492(BI rate).

Based on the result of t-test, the rupiah exchange rate has a significant influence by the value $-3,017$. Inflation and $B I$ rate partially has not significant influence to Net Asset Value (NAV) Sharia Equity Fund with result $t-0,144$ for Inflation and - 1,431 for Bl rate. The result of simultaneous test showed that inflation, rupiah exchange rate, and BI rate has significant effect to Net Asset Value (NAV) Sharia Equity Fund with significance value 0,004. The suggestions was investment manager is to keep attention to macro economic factors such as inflation, rupiah exchange rate, and $\mathrm{Bl}$ rate. In order to invest in sharia equity fund can contribute a maximum profit.
\end{abstract}

Keywords : inflation, rupiah exchange rate, BI rate, net asset value, sharia equity fund.

\section{PENDAHULUAN}

\section{Latar Belakang}

Memilih investasi yang aman dan menguntungkan memang menjadi tujuan semua pihak, namun tidak jarang investasi palsu, bersentuhan dengan perusahaan yang memproduksi barang haram dan alih-alih memberikan keuntungan tinggi sangat banyak dijumpai di masyarakat. Hal ini diperlukan adanya reksa dana saham sesuai syariah sebagai alternatif investasi bagi investor yang beragama Islam di Indonesia, yang menginginkan investasi dengan memperoleh pendapatan dengan cara yang halalanthoyyibah.

Dalam ayat al Quran di surat al Maidah (5) ayat 88, Allah SWT. berfirman

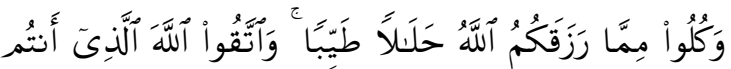

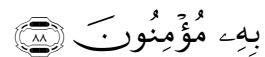

Wakulū mimma razaqakuumul-Lahu halalan tayyiba(n), wat-taqul-Laha al-ladzī antum bihī mu'minūna

Artinya, "dan makanlah makanan yang halal lagi baik dari apa yang Allah telah rezekikan kepadamu, dan bertakwalah kepada Allah yang kamu beriman kepada-Nya."

Ayat diatas merupakan perintah Allah subhanahu wata'ala kepada kita manusia agar makan makanan yang halal dan baik. Dapat diperluas lagi bahwasannya tidak hanya berkutat pada makanan, namun bisnis, perdagangan, transaksi dan rezki yang kita cari dan kita peroleh wajib memenuhi aspek kehalalan. Halal dari

1) jurnal ini merupakan bagian dari skripsi yang ditulis oleh (Ainur Rachman, NIM:040810319), yang diuji pada (6 Juli 2015) 
aspek hukum dan baik dari aspek substansinya. Dalam hadist nabi beliau SAW bersabda

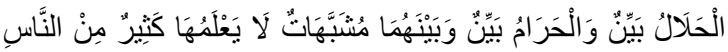

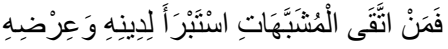

Al-halā̄lu bayyinun wa al-haramu bayyinun wa bainahumā musyabbahātun laa ya'lamuhā katsīrun min-nāsi fa man attaqo al-musyabbahāti istabron lidinihi wa 'irdhihi

Artinya, "Yang halal sudah jelas dan yang haram juga sudah jelas. Namun diantara keduanya ada perkara syubhat (samar) yang tidak diketahui oleh banyak orang. Maka barangsiapa yang menjauhi diri dari yang syubhat berarti telah memelihara agamanya dan kehormatannya...." (HR. Bukhari no. 50).

Sangat jelas gambaran Rasulullah SAW. tentang perbedaan halal dan haram, dan peringatan beliau tentang perkara yang syubhat, dimana jika seorang muslim mampu menjaga dari perkara tersebut maka dia telah benar benar menjaga agama yang dicintainya dan juga kehormatannya sendiri. Aturan Allah wajiblah dipenuhi, ditaati dan dikerjakan, karena Allah adalah raja dari segala raja.

Baik buruknya suatu investasi tidak terlepas dari adanya faktor - faktor lain yang mempengaruhi, faktor - faktor yang diduga memiliki pengaruh terhadap net asset value (NAV) atau Nilai Aktiva Bersih (NAB) reksa dana saham syariah adalah tingkat Inflasi di dalam negeri, Nilai Tukar Rupiah, dan BI Rate. Secara teori, faktor faktor tersebut berkaitan dengan net asset value (NAV) reksa dana saham syariah sehingga di harapkan investor dapat menjadikannya sebagai indikator untuk mengetahui NAV/NAB per unit reksa dana saham syariah.

Inflasi adalah proses kenaikan harga-harga umum secara terus menerus, yang berakibat menurunnya daya beli masyarakat karena secara riil tingkat pendapatan juga menurun (Putong, 2002:185).

Menurut Suta (2000) dalam Hifdzia (2012:8), fluktuasi nilai rupiah terhadap mata vang asing yang stabil akan sangat mempengaruhi iklim investasi dalam negeri, khususnya pasar modal. Terkait denga investasi.

Menurut Samuelson dan Nordhaus (2004:197) suku bunga adalah biaya untuk meminjam vang dan diukur dalam dolar per tahun untuk setiap satu dolar yang dipinjamnya, jika diterapakan dalam kondisi Indonesia maka suku bunga merupakan jasa peminjaman vang dari bank kepada nasabah.. Jika BI rate dinaikkan, yang akan terjadi adalah investor akan memilih alternatif investasi yang memberikan pendapatan yang lebih tinggi. Akibatnya instrumen instrumen pasar modal seperti saham tidak diminati bahkan dijual dan beralih ke perbankan. Hal tersebut menyebabkan harga saham menurun sehingga keuntungan reksa dana saham juga mengalami penurunan. Dan begitu pula sebaliknya. 


\section{Rumusan Masalah}

1. Apakah inflasi berpengaruh signifikan secara parsial terhadap Net Asset Value Reksa Dana Saham Syariah?

2. Apakah nilai tukar rupiah berpengaruh signifikan secara parsial terhadap Net Asset Value Reksa Dana Saham Syariah?

3. Apakah BI Rate berpengaruh signifikan secara parsial terhadap Net Asset Value Reksa Dana Saham Syariah?

4. Apakah inflasi, nilai tukar rupiah, BI rate berpengaruh signifikan secara simultan terhadap Net Asset Value Reksa Dana Saham Syariah?

\section{Tujuan Penelitian}

Berdasarkan latar belakang serta rumusan masalah yang dikemukakan diatas maka dapat disebutkan bahwa tujuan penelitian ini adalah untuk mengetahui apakah terdapat pengaruh signifikan secara parsial dan secara simultan antara inflasi, nilai tukar rupiah, dan $\mathrm{Bl}$ Rate terhadap net asset value reksa dana saham syariah

\section{II.LANDASAN TEORI}

\section{Investasi Syariah}

Allat SWT berfirman dalam surat alJaatsiyah (45) ayat 13

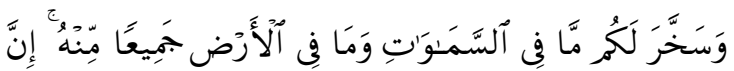

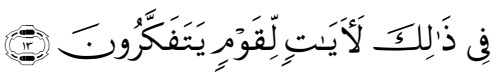

"wasakhkhara lakum mā fīs-samaawaati wamā fll-ardhi jamīan minh(U). Inna fi dzālika la-āyātil-liqaumin yatafakkarūn(a)"
Artinya, "dan Dia telah menundukkan untukmu apa yang di langit dan apa yang di bumi semuanya, (sebagai rahmat) daripada-Nya. Sesungguhnya pada yang demikian itu benar-benar terdapat tanda-tanda (kekuasaan Allah) bagi kaum yang berfikir."

Allah SWT. Hanya menyediakan berbagai aktifitas yang masih mentah dibumi ini, sementara tugas manusia sebagai khalifah-lah yang mengeksplorasi sehingga berkemanfaatan secara kolektif Investasi syariah dalam pengertian yang sederhana, tak lain adalah usaha perkongsian atau syirkah, dimana satu pihak pemodal menanamkan danaya dalam sebuah usaha riil yang dilaksanakan oleh pihak lain. Bentuk syirkah yang cukup dikenal dalam Islam adalah musyarakah dan mudharabah. Musyarakah menurut Ibnu Rusyd dalam Bidayatul Mujtahid II hal 253-257 yang dikutip. Oleh Antonio (2001:90), mendefinisikan sebagai akad kerjasama antara dua pihak atau lebih untuk suatu usaha tertentu di mana masing-masing pihak memberikan kontribusi dana (atau amal/expertise) dengan kesepakatan bahwa keuntungan dan resiko akan ditanggung bersama sesuai dengan kesepakatan. Mudharabah lazim dikenal sebagai akad investasi, diartikan perjanjian atas suatu jenis perkongsian, dimana pihak pertama (shahib al-maal) menyediakan dana, dan pihak kedua (mudharib) bertanggung jawab atas pengelolaan usaha. Hasil usaha dibagikan 
sesuai dengan nisbah (porsi bagi hasil) sesuai dengan ketentuan yang telah disepakati bersama sejak awal (Yusuf dan Wiroso, 2011:93).

\section{Reksa Dana Syariah}

Salah satu tujuan dari reksa dana syariah adalah memenuhi kebutuhan kelompok investor yang ingin memperoleh pendapatan investasi dari sumber yang bersih dan dapat dipertanggung jawabkan secara religius, serta sejalan dengan prinsip-prinsip syariah. Dari sisi tujuan reksa dana syariah dapat disejajarkan dengan social responsible investment (SRI) atau ethical investment, socially aware investment, dan valuebased investment. Tujuan utama reksa dana syaraih bukan semata-mata mencari keuntungan, tetapi juga memiliki tanggung jawab sosial terhadap lingkungan, komitmen terhadap nilai-nilai yang diyakini tanpa harus mengabaikan keinginan investornya (Ghufron dkk,2005:15-16).

Adapun landasan hukum syariah dari reksa dana syariah menurut Fatwa Dewan Syariah Nasional Nomor: 20/DSNMUI/IV/2001 adalah:

1. Q.S Al-Maidah (5): 1

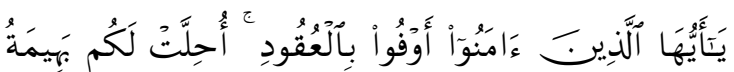

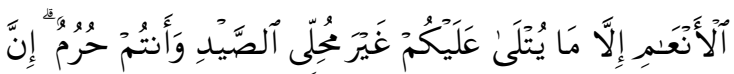

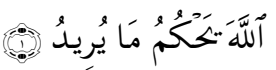

Yaā ayyuhal-ladzīna āmanū aufū bil'vqūd(i), uhillat lakum bahīmatul-an'āmi ilā mā yutlā 'alaikum ghaira muhilis-saidi wa antum hurum (mun), innal-Lāha yahkumu mā yurīd(u).

Artinya, "Hai orang-orang yang beriman, penuhilah aqad-aqad itu. Dihalalkan bagimu binatang ternak, kecuali yang akan dibacakan kepadamu. (yang demikian itu) dengan tidak menghalalkan berburu ketika kamu sedang mengerjakan haji. Sesungguhnya Allah menetapkan hukum-hukum menurut yang dikehendakiNya".

Ayat tersebut diatas menjelaskan tentang kewajiban seorang muslim dalam menepati janji, dalam ayat ini janji disebutkan sebagai akad. Janji merupakan sesuatu yang berharga dan harus dipenuhi ketika sudah terucap, atau berazzam.

2. Q.S Al-Baqarah (2): 279
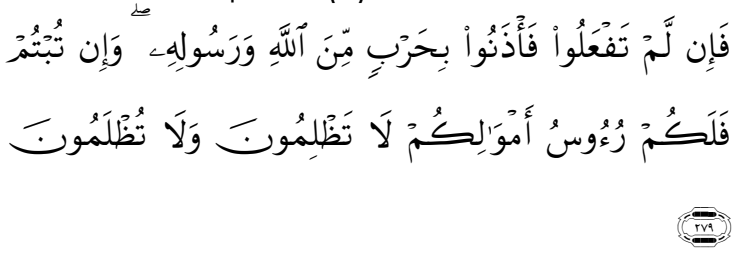

Fain lam taf'alū fa'dzanū biharbin minalLāhi warasūlih(i), wa in tub'tum falakum ru'ūsu amwālikum lā tadzlimūna walā tudzlamūn(a)

Artinya, "Maka jika kamu tidak mengerjakan (meninggalkan sisa riba), Maka ketahuilah, bahwa Allah dan RasulNya akan memerangimu. dan jika kamu bertaubat (dari pengambilan riba), Maka bagimu pokok hartamu; kamu tidak Menganiaya dan tidak (pula) dianiaya."

Dalam ayat ini Allah SWT memberi peringatan tentang seseorang yang enggan meninggalkan riba yang telah 
dilakukannya dengan mengumumkan perang terhadapnya, bukan hanya Allah yang Maha Pedih siksaannya, namun juga Rasul-Nya diajak Allah untuk memerangi orang seperti ini.

3. Hadits riwayat Tirmidzi dari 'Amr bin 'Auf:

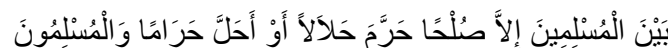

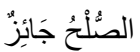

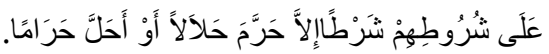
Ash sholihuzun jādi baina al-muslimina ilā shullihan harromā halālan au ahalla harōman wa al-muslimūna 'alā syurūtihim syarthon illā harroma halālan au ahalla harōman.

Artinya, "Perjanjian itu dapat dilakukan di antara kaum Muslimin kecuali perjanjian yang mengharamkan yang halal atau menghalalkan yang haram: dan kaum Muslimin terikat dengan syarat-syarat mereka kecuali syarat yang mengharamkan yang halal atau menghalalkan yang haram."

Penjelasan hadits diatas adalah dalil haram halal perdagangan diatas segalanya. Dalam artian ketika kita akan melaksanakan transaksi, baik barang maupun jasa, maka kejelasan hukum dan status halal adalah mutlak, karena tidak mungkin seorang muslim berani melakukan sesuatu yang dilarang agama.

\section{Net Asset Value (NAV) per unit Reksa Dana Saham Syariah}

Konsep Net Asset Value (NAV) adalah nilai aktiva reksa dana setelah dikurangi nilai kewajiban reksa dana tersebut (Rahardjo, 2004:71). Net Asset
Value merupakan data historis untuk melihat dan mengamati data-data tinggi rendahnya pengambilan investasi dari reksadana (Elvira dan Fiteriyanto, 1997:23).

Inflasi dalam Perspektif Islam

Inflasi secara umum sering dipahami sebagai meningkatnya harga barang secara keseluruhan. Dengan demikian, terjadi penurunan daya beli vang decreasing purchasing power of money. Oleh karena itu, menurut penganut paham ini, pengambil bunga vang sangatlah logis sebagai kompensasi penurunan daya beli uang selama dipinjamkan. Argumentasi tersebut memang sangat tepat seandainya dalam dunia ekonomi yang terjadi hanyalah inflasi saja tanpa deflasi atau stabil (Antonio, 2001:76).

Dalam surat at Taubah (9) ayat 3435 Allah SWT Berfirman:

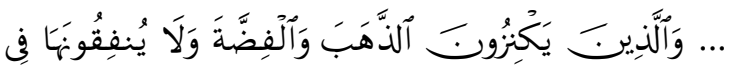

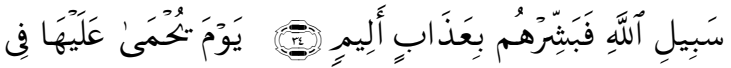

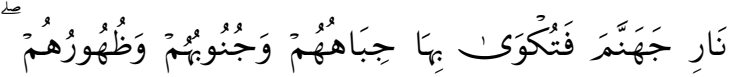

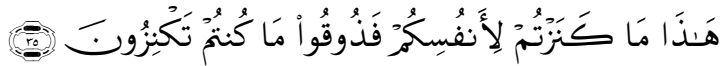
Wa al-ladzinna yaknizūnadz-dzahaba walfi'dlota wa lā yunfiqūnahā fī sabili-Lāhi faba'syirhum bi'adzābin aliim(in). Yauma yuhmā 'alaihā fĩ nāri jahannama fatukwā bihā jibā huhum wa junūbuhum wa dzuhuuruhum, haadzaa mā kanaztum lianfusikum fadzūqū mā kuntum taknizūn(a).

Artinya, "....dan orang-orang yang menyimpan emas dan perak dan tidak menafkahkannya pada jalan Allah, Maka 
beritahukanlah kepada mereka, (bahwa mereka akan mendapat) siksa yang pedih,

35. pada hari dipanaskan emas perak itu dalam neraka Jahannam, lalu dibakar dengannya dahi mereka, lambung dan punggung mereka (lalu dikatakan) kepada mereka: "Inilah harta bendamu yang kamu simpan untuk dirimu sendiri, Maka rasakanlah sekarang (akibat dari) apa yang kamu simpan itu."

Ibnu Katsir dalam tafsirnya Qur'anil 'Adzim (II/351-352) menyatakan bahwa setiap orang yang mencintai sesuatu dan mendahulukannya dibanding ketaatan kepada Allâh, niscaya ia akan disiksa dengannya. dikarenakan orang-orang yang disebut pada ayat ini lebih menyenangi untuk menimbun harta kekayaannya daripada mentaati Allâh Ta'ala, maka dari itu kelak mereka disiksa dengan harta itu. Para penimbun harta kekayaan. Harta kekayaan yang sangat ia cintai, kelak pada hari kiamat menjadi hal yang paling menyedihkan di neraka Jahannam, harta itu akan dipanaskan, lalu digunakan untuk membakar dahi, perut, dan punggung mereka.

\section{Nilai Tukar Rupiah}

Definisi nilai tukar atau kurs (foreign exchange rate) merupakan harga mata vang suatu negara terhadap mata vang negara lain (Pilbeam,2006:72). Dalam hal ini adalah mata uang rupiah terhadap mata uang asing. Karena nilai tukar ini mencakup dua mata uang, maka titik keseimbangannya ditentukan oleh sisi penawaran dan permintaan dari kedua mata vang tersebut. Pengertian lain dari nilai tukar ditulis oleh Blanchard (2006) yakni Nominal exchange rate as the price of the domestic currency in term of foreign currency.

\section{BI Rate (Suku Bunga Bank Indonesia)}

Menurut Karl dan Fair (2001:52), suku bunga adalah pembayaran bunga tahunan. Dari suatu pinjaman, dalam bentuk persentase dari pinjaman yang diperoleh dari jumlah bunga yang diterima tiap tahun dibagi dengan jumlah pinjaman. Pengertian suku bunga lainnya menurut Sunariyah (2004:17), adalah harga dari pinjaman. Suku bunga dinyatakan sebagai persentase vang pokok per unit waktu.

\section{Hubungan antar Variabel}

Hubungan antara Inflasi dengan Net Asset Value (NAV) Reksa Dana Saham Syariah.

Dari sisi riil ekonomi, kenaikan inflasi akan menyebabkan harga-harga barang maupun jasa meningkat. Hal ini menyebabkan omset perusahaan akan turun sehingga pendapatan laba perusahaan juga menurun. Selanjutnya harga saham perusahaan juga akan turun, dengan diikuti Net Asset Value (NAV) menurun. Jika dilihat dari sektor pasar modal, ketika inflasi tinggi, menyebabkan suku bunga yang tinggi pula, hal ini memungkinkan investor akan mengalihkan investasi ke pasar vang. Dengan cara menjual sahamnya, maka mengakibatkan harga saham menurun, dan Net Asset Value (NAV) juga menurun. 
Putratama (2007) mengatakan bahwa tingkat inflasi berpengaruh negatif terhadap NAB reksa dana syariah jika dampak inflasi mengurangi konsumsi dan daya beli masyarakat. Selain itu, inflasi juga dapat berpengaruh positif jika penyebab inflasi adalah sektor moneter yang mencakup jumlah uang beredar, seperti yang dikatakan oleh Arisandi (2009).

Dari sisi emiten (penerbit saham), inflasi yang terjadi merupakan dampak dari naiknya harga barang dan jasa di pasar, sehingga membuat perusahaaan mengefisiensi biaya operasional perusahaan. Hal ini membuat kinerja perusahaan menurun, sehingga nilai saham juga akan turun dan menyebabkan Net Asset Value (NAV) menurun. Kenaikan tingkat inflasi menyebabkan daya beli konsumen menurun karena semua harga barang meningkat, sedangkan pendapatan konsumen tetap. Harga saham pun menurun dan mengakibatkan turunnya kinerja reksadana saham (Putri, 2012; Rombe, 2012 dalam Pasaribu dan Kowanda, 2014).

\section{Hubungan antara Nilai Tukar Rupiah dengan Net Asset Value (NAV) Reksa Dana Saham Syariah.}

Nilai tukar adalah nilai mata uang suatu negara diukur dari nilai satu unit mata vang terhadap mata vang negara lain. Besarnya jumlah mata uang tertentu yang diperlukan untuk memperoleh satu unit valuta asing disebut dengan Kurs
Mata Uang Asing. Apabila kondisi ekonomi suatu negara mengalami perubahan, maka biasanya diikuti oleh perubahan nilai tukar secara subtansional. (Sadono, 2002:178). Resiko nilai kurs merupakan resiko yang timbul akibat pengaruh perubahan nilai tukar mata vang domestik dengan nilai tukar mata vang negara lain (asing). Perusahaan yang menggunakan mata vang asing dalam menjalankan aktivitas operasional dan investasinya akan menghadapi resiko nilai tukar (kurs). Perubahan nilai tukar vang tidak diantisipasi oleh perusahaan akan berpengaruh terhadap nilai perusahaan tersebut.

Dari sisi emiten jika nilai tukar rupiah menurun, maka hutang yang harus dibayar akan meningkat, investasi menurun sehingga kinerja perusahaan juga ikut menurun. Akibatnya harga saham menurun, dan berimbas pada menurunnya Net Asset Value (NAV). Dari sisi Investasi turunnya nilai tukar rupiah terhadap mata uang asing membuat para investor ragu akan kinerja emiten dapat berkembang dengan baik. Selain itu, sulitnya untuk mengantisipasi gerak fluktuasi rupiah membuat para investor bimbang. Hal tersebut dapat menyebabkan indeks-indeks di bursa efek yang terus menerus berfluktuasi tersebut cenderung menurun dengan tajam, maka akan menyebabkan total investasi menurun hal ini berakibat NAV perusahaan emiten turun pula (Rahmah, 2011). 
Hubungan antara $\mathrm{BI}$ Rate dengan Net Asset Value (NAV) Reksa Dana Saham Syariah.

Dari sisi investor $\mathrm{Bl}$ rate menjadi penggerak untuk berinvestasi. Gerakan ini dapat menguatkan investasi ketika $\mathrm{BI}$ rate menurun sehingga semua investasi dialihkan ke pasar modal. Seiring dengan itu maka kinerja perusahaan akan meningkan sehingga nilai saham juga meningkat, hal ini berdampak Net Asset Value (NAV) juga meningkat. (Huda dan Nasution, 2007:128)

Dari sisi emiten jika $\mathrm{Bl}$ rate dipandang sangat mempengaruhi kinerja perusahaan. Jika $\mathrm{Bl}$ rate meningkat maka mengurangi modal pinjaman, hal ini membuat kinerja perusahaan menurun, sehingga nilai saham dipasaran anjlok, akibatnya saham dibagi juga akan turun. Karena kinerja perusahaan melemah maka Net Asset Value (NAV) di pasar modal juga menjadi buruk. Menurut Nurlaili (2012:11)., perubahan suku bunga SBI dapat mempengaruhi variablitas dari return suatu investasi. Hal ini dapat terjadi karena jika suku bunga meningkat, maka harga saham akan cenderung turun turun, begitupun sebaliknya. Karena jika tingkat suku bunga naik maka investor akan berekspektasi memperoleh return yang lebih baik dari instrumen investasi yang terkait hal itu, seperti contohnya deposito. Sehingga minat investor akan berpindah dari investasi saham ke deposito. Hal ini sesuai dengan hasil penelitian yang dilakukan, hasil penelitiannya menunjukkan bahwa BI rate berpengaruh secara signifikan terhadap nilai aktiva bersih reksa dana saham.

\section{Model Analisis}

Berdasarkan hipotesis di atas, penelitian ini menggunakan analisis dengan kerangka kerja penelitian untuk menjelaskan hubungan antara variabel independen dan variabel dependen. Model analisis penelitian ini adalah:

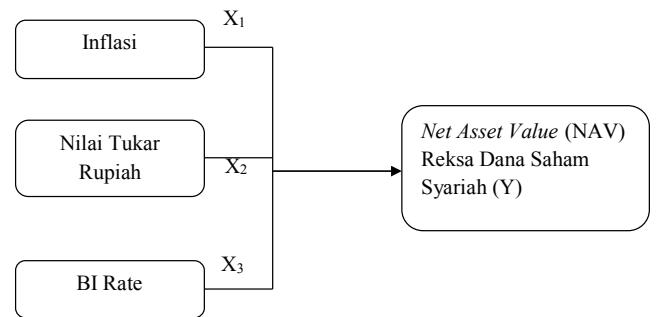

Sumber: Diolah dari berbagai sumber.

Gambar 1. Model Analisis

\section{METODE PENELITIAN}

Pendekatan penelitian yang digunakan dalam penelitian ini adalah pendekatan kuantitatif, yang bertujuan untuk menguji hipotesis, dengan data yang terukur dan menghasilkan kesimpulan yang dapat digeneralisir. Langkah awal dalam melakukan penelitian kuantitatif dimulai dengan menentukan hipotesis, langkah selanjutnya membuat model analisis, identifikasi variabel, definisi operasional, pengumpulan data sekunder berdasarkan populasi dan sampel penelitian, serta melakukan analisis. Variabel yang digunakan dalam penelitian ini dapat diidentifikasikan menjadi 2 (dua) variabel, yaitu: 
a. Variabel independen (X), yaitu inflasi, nilai tukar rupiah, dan BI rate.

b. Variabel dependen (Y), yaitu net asset value reksa dana saham syariah.

Berdasarkan variabel-variabel yang digunakan, maka hubungan antar variabel dapat dinyatakan dalam fungsi sebagai berikut:

$$
\mathbf{Y}=f\left(X_{1}, X_{2}, X_{3}\right)
$$

Bentuk persamaan regresi dapat dirumuskan sebagai berikut :

$$
Y=a+\beta_{1} X_{1}+\beta_{2} X_{2}+\beta_{3} X_{3}+e
$$

Keterangan:

$Y=$ variabel endogen (net asset value reksa dana saham syariah)

$\mathrm{a}_{0}=$ konstanta

$\beta_{1}, \beta_{2}, \beta_{3}=$ koefisien regresi masing-masing variabel eksogen

$X_{1}=$ variabel eksogen 1 (inflasi)

$X_{2}=$ variabel eksogen 2 (nilai tukar rupiah)

$\mathrm{X}_{3}=$ variabel eksogen 3 (BI Rate)

$e=$ koefisien penggangu (error)

Dari model analisa regresi linear

yang digunakan, terdapat beberapa asumsi klasik yang dapat digunakan untuk mengestimasi hasil agar tidak ada penyimpangan sehingga dapat memberikan informasi yang sesuai dengan data yang tersedia. Asumsi klasik tersebut adalah, uji multikolinearitas, uji autokorelasi, uji heteroskedastisitas, dan uji normalitas.

\section{Definisi Operasional}

Inflasi $\left(X_{1}\right)$

Inflasi adalah kecenderungan harga - harga untuk naik secara umum dan terus menerus (Mankiw,2006:145).
Pada penelitian ini inflasi diambil dari data inflasi bulanan yang dikeluarkan oleh Badan Pusat Statistik (BPS) sejak Januari 2011 sampai dengan Desember 2014 dalam persen.

\section{Nilai Tukar Rupiah ( $\left.\mathrm{X}_{2}\right)$}

Nilai tukar rupiah diddefiniskan sebagai harga mata uang suatu negara terhadap mata vang negara lain (Pilbeam, 2006:72). Pada penelitian ini nilai tukar rupiah diambil dari data nilai tukar rupiah bulanan yang dikeluarkan oleh Bank Indonesia sejak Januari 2011 sampai dengan Desember 2014 dalam rupiah.

\section{BI Rate $\left(\mathrm{X}_{3}\right)$}

Menurut Karl dan Fair (2001:52), suku bunga adalah pembayaran bunga tahunan dari suatu pinjaman, dalam bentuk persentase dari pinjaman yang diperoleh dari jumlah bunga yang diterima tiap tahun dibagi dengan jumlah pinjaman. Pengertian suku bunga menurut Sunariyah (2004:17) adalah harga dari pinjaman. Suku bunga dinyatakan sebagai persentase vang pokok per unit waktu

Pada penelitian ini BI rate diambil dari data $\mathrm{Bl}$ rate bulanan yang dikeluarkan oleh Bank Indonesia sejak Januari 2011 sampai dengan Desember 2014 dalam persen.

\section{Variabel Terikat $(\mathrm{Y})$}

Net Asset Value merupakan data historis untuk melihat dan mengamati data-data tinggi rendahnya pengambilan investasi dari reksadana (Elvira dan Fiteriyanto,1997:23). Pada penelitian ini net 
asset value reksa dana saham syariah diambil dari data net asset value reksa dana saham harian yang dikeluarkan oleh Bapepam-LK sejak Januari 2011 sampai dengan Desember 2014 dalam bentuk rupiah.

\section{Populasi dan Sampel}

Populasi adalah keseluruhan gejala atau satuan yang ingin diteliti (Prasetyo dan Lina,2012:118). Populasi dalam penelitian ini adalah net asset value reksa dana saham syariah. Anshori dan Iswati (2009:94) menjelaskan bahwa sampel adalah bagian dari jumlah dan karakteristik yang dimiliki oleh populasi, sedangkan sampel dalam penelitian ini adalah net asset value PNM Ekuitas Syariah yang diambil 48 bulan terakhir tiap variabel dengan periode Januari 2011 hingga Desember 2014, sehingga totalnya 192 sampel. Metode pemilihan sampel yang digunakan dalam penelitian ini adalah metode pemilihan sampel non acak (non probability sampling) secara purposive sampling. Non probability sampling adalah teknik pengambilan sampel yang tidak member peluang atau kesempatan sama bagi setiap unsur atau anggota populasi untuk dipilih menjadi sampel sedangkan purposive sampling merupakan teknik penentuan sampel dengan pertimbangan tertentu. (Anshori dan Iswati, 2009:105).

\section{HASIL DAN PEMBAHASAN}

\section{Hasil Uji F}

Tabel 3.

Hasil Uji Secara Simultan (Uji F)

\begin{tabular}{|c|c|c|c|c|c|}
\hline Model & $\begin{array}{l}\text { Sum of } \\
\text { Squares }\end{array}$ & Df & $\begin{array}{l}\text { Mean } \\
\text { Square }\end{array}$ & $\begin{array}{c}\mathrm{F} \\
\text { hitung }\end{array}$ & Sig. \\
\hline $\begin{array}{c}\text { Regressi } \\
\text { on }\end{array}$ & 47930 & 3 & 15977 & 5,144 & 0,0 \\
\hline Residual & 136667 & 44 & 3106 & & \\
\hline Total & 184596 & 47 & & & \\
\hline
\end{tabular}

Sumber: Hasil Penelitian, Lampiran 5. 2015 (diolah)

Hasil uji $\mathrm{F}$ diperoleh nilai $\mathrm{F}$ hitung $=$ $5,144>F$ tabel 2,816 (df1=3, df2 $=44$, $a=0,05)$ dan nilai signifikansi $=0,004<0,05$, maka disimpulkan bahwa inflasi, nilai tukar rupiah dan $\mathrm{BI}$ rate secara simultan berpengaruh signifikan terhadap net asset value reksa dana saham syariah. Hal ini berarti adanya peningkatan inflasi, nilai tukar rupiah dan $\mathrm{Bl}$ rate secara bersamasama akan merubah net asset value reksa dana saham syariah.

Berdasarkan hasil tersebut disimpulkan bahwa hipotesis keempat penelitian yang menyatakan bahwa inflasi, nilai tukar rupiah dan $\mathrm{BI}$ rate berpengaruh secara simultan terhadap net asset value reksa dana saham syariah dapat diterima dan dibuktikan kebenarannya.

\section{Pembahasan}

Pengaruh Inflasi Terhadap Net Asset Value Reksa Dana Saham Syariah

Berdasarkan hasil uji $t$, diketahui bahwa inflasi tidak berpengaruh secara 
signifikan secara parsial terhadap Net Asset Value (NAV) reksa dana periode Januari 2011-Desember 2014. Hasil tersebut dibuktikan dari hasil uji $\dagger$ hitungnya sebesar 0,144 dan t tabelnya sebesar 2,015 sehingga nilai $\dagger$ hitung $<\dagger$ tabel berdasarkan hal tersebut maka dalam penelitian ini Ho diterima. Jika dilihat dari nilai signifikansinya yakni sebesar 0,886 dimana > a 0,05, maka kesimpulannya inflasi tidak berpengaruh signifikan secara parsial.

Inflasi adalah kecenderungan harga harga untuk naik secara umum dan terus menerus (Mankiw, 2006:145) Terjadinya inflasi akan menyebabkan menurunnya total real return investasi pendapatan yang diterima dari investasi dalam reksa dana, terdapat kemungkinan tidak dapat menutup kehilangan karena menurunnya daya beli (loss of purchasing power). Hal ini bertolak belakang dengan penelitian yang dilakukan Susetyo (2013) yang berjudul analisa pengaruh inflasi terhadap kinerja reksadana saham di Indonesia periode 2002-2012, menyebutkan bahwa antara variabel inflasi dengan kinerja reksadana saham di Indonesia berhubungan negatif. Jika inflasi naik maka, kinerja reksa dana saham akan menurun.

Dari hasil penelitian ini yang menyebutkan inflasi tidak berpengaruh signifikan terhadap Net Asset Value (NAV) reksa dana saham syariah, kita dapat melihat bagaimana kekuatan reksa dana saham syariah tidak goyah walaupun terjadi inflasi.

Sejalan dengan itu Allah SWT Berfirman dalam surat surat at Taubah (9) ayat $34-35$ :

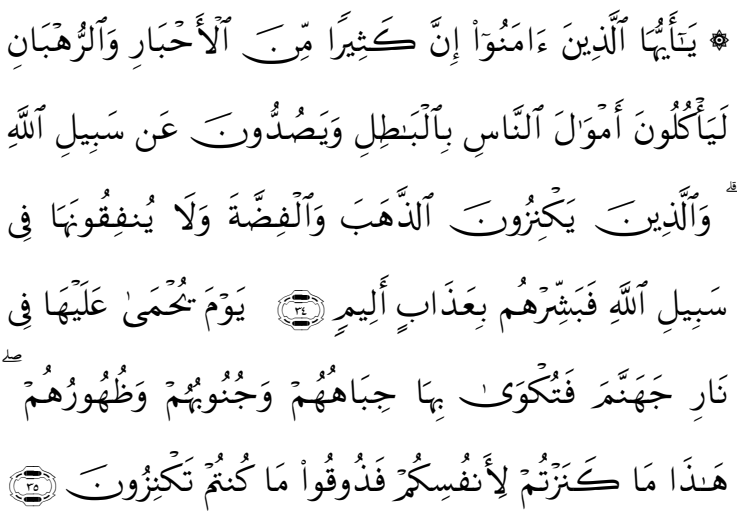

Wa al-ladzinna yaknizūnadz-dzahaba walfi'dlota wa lā yunfiqūnahā fì sabili-Lāhi faba'syirhum bi'adzābin aliim(in). Yauma yuhmā 'alaihā fĩ nāri jahannama fatukwā bihā jibā huhum wa junūbuhum wa dzuhuuruhum, haadzaa mā kanaztum lianfusikum fadzūqū mā kuntum taknizūn(a).

"....dan orang-orang yang menyimpan emas dan perak dan tidak menafkahkannya pada jalan Allah, Maka beritahukanlah kepada mereka, (bahwa mereka akan mendapat) siksa yang pedih. pada hari dipanaskan emas perak itu dalam neraka Jahannam, lalu dibakar dengannya dahi mereka, lambung dan punggung mereka (lalu dikatakan) kepada mereka: "Inilah harta bendamu yang kamu simpan untuk dirimu sendiri, Maka rasakanlah sekarang (akibat dari) apa yang kamu simpan itu."

Dari Ibnu Katsir dalam tafsirnya Qur'anil 'Adzim (II/351-352) menyatakan bahwa ayat ini mengungkapkan tentang setiap orang yang mencintai sesuatu dan 
mendahulukannya dibanding ketaatan kepada Allâh, niscaya ia akan disiksa dengannya. dikarenakan orang-orang yang disebut pada ayat ini lebih menyenangi untuk menimbun harta kekayaannya daripada mentaati Allâh Ta'ala, maka dari itu kelak mereka disiksa dengan harta itu. Para penimbun harta kekayaan. Harta kekayaan yang sangat ia cintai, kelak pada hari kiamat menjadi hal yang paling menyedihkan di neraka Jahannam, harta itu akan dipanaskan, lalu digunakan untuk membakar dahi, perut, dan punggung mereka.

Pengaruh Nilai Tukar Rupiah Terhadap Net Asset Value Reksa Dana Saham Syariah

Pengaruh variabel nilai tukar rupiah secara parsial terhadap net asset value reksa dana saham syariah dapat dilihat dari hasil uji † yang menyatakan bahwa pembiayaan investasi berpengaruh signifikan secara parsial terhadap net asset value reksa dana saham syariah periode Januari 2011Desember 2014. Hasil tersebut dibuktikan dari nilai hasil uji † hitungnya sebesar 3,017 dan † tabelnya 2,015 sehingga nilai $\dagger$ hitung > † tabel. Berdasarkan hal tersebut maka Ho ditolak dan jika dilihat dari nilai signifikan sebesar 0,004 kurang dari 0,05 dan kesimpulannya nilai tukar rupiah berpengaruh signifikan terhadap net asset value (NAV) reksa dana saham syariah secara parsial.

Nilai tukar rupiah adalah nilai tukar/kurs (foreign exchage rate) merupakan harga mata uang suatu negara terhadap mata vang negara lain (Pilbeam, 2006:72). Nilai tukar uang/kurs merupakan variabel makroekonomi yang turut mempengaruhi volatilitas harga saham. Hal ini bertolak belakang dari penelitian yang dilakukan oleh Rahmah (2011) yang berjudul pengaruh SBIS, IHSG, dan nilai tukar rupiah terhadap nilai aktiva bersih (NAB) Danareksa Syariah berimbang, menyatakan bahwa nilai tukar rupiah tidak memiliki pengaruh terhadap pertumbuhan NAB Danareksa Syariah berimnbang.

Namun penelitian ini didukung oleh penelitian dari Agustina (2012) yang berjudul pengaruh fluktuasi jumlah uang beredar, nilai tukar rupiah dan $\mathrm{BI}$ rate terhadap nilai aktiva bersih per unit (nab/unit) reksa dana syariah, menjelaskan bahwa nilai tukar berpengaruh signifikan dengan pengaruh negatif terhadap NAB/unit reksa dana syariah. Jika nilai tukar rupiah menurun, maka maka hutang yang harus dibayar akan meningkat, investasi menurun sehingga kinerja perusahaan juga ikut menurun. Akibatnya harga saham menurun, dan berimbas pada menurunnya Net Asset Value (NAV).

\section{Pengaruh BI Rate Terhadap Net Asset} Value Reksa Dana Saham Syariah

Pengaruh BI Rate terhadap net asset value reksa dana saham syariah dapat dilihat dari hasil uji hipotesis $†$ yang menyatakan bahwa Bl Rate tidak berpengaruh signifikan secara parsial terhadap net asset value reksa dana 
saham syariah periode Januari 2011Desember 2014. Hasil tersebut dibuktikan dari nilai hasil uji † hitungnya sebesar 1,431 dan $t$ tabel sebesar 2,015 sehingga $\dagger$ hitung < † tabel. Berdasarkan hal tersebut maka dalam penelitian ini Ho diterima dan jika dilihat dari nilai signifikan sebesar 0,159 sehingga lebih dari 0,05 kesimpulannya $\mathrm{Bl}$ Rate tidak berpengaruh signifikan terhadap net asset value reksa dana saham syariah secara parsial. Berdasarkan hasil ini, hipotesis ketiga penelitian yang menduga BI Rate berpengaruh signifikan terhadap net asset value reksadana saham syariah tidak terbukti kebenarannya. Artinya bahwa reksa dana saham syariah sangat berpotensi menjadi reksa dana saham unggulan karena tidak terikat dengan $\mathrm{Bl}$ rate sehingga para investor dapat kapan saja menginvestasikan dananya untuk reksa dana saham syariah.

Tingkat suku bunga merupakan pembayaran bunga tahunan dari suatu pinjaman, dalam bentu persentasi dari pinjaman yang diperoleh dari jumlah bunga yang diterima tiap tahun dibagi dengan jumlah pinjaman (Karl dan Fair, 2001:52). Hal ini bertolak belakang dengan penelitian yang dilakukan oleh Agustina (2012) yang berjudul pengaruh fluktuasi jumlah vang beredar, nilai tukar rupiah dan $\mathrm{BI}$ rate terhadap nilai aktiva bersih per unit (nab/unit) reksa dana syariah, dan Nuraili (2012) yang berjudul pengaruh indeks harga saham gabungan dan rate Bank Indonesia terhadap nilai aktiva bersih reksa dana saham, yang menyatakan bahwa $\mathrm{BI}$ rate berpengaruh signifikan terhadap nilai aktiva bersih reksa dana saham. Sedangkan menurut penelitian dari Brianto (2013) yang berjudul analisis pengaruh suku bunga Bank Indonesia terhadap reksa dana saham di Indonesia tahun 2002-2012, menyatakan bahwa $\mathrm{BI}$ rate memiliki pengaruh negatif terhadap reksa dana saham di indonesia tahun 2002-2012.

Penelitian terdahulu tersebut menyatakan bahwa $\mathrm{BI}$ Rate memiliki pengaruh terhadap net asset value (NAV) reksa dana saham konvensional maupun reksa dana saham syariah. BI Rate juga memiliki pengaruh negatif terhadap reksa dana saham, dimana jika BI Rate menurun sehingga semua investasi dialihkan ke pasar modal. Seiring dengan itu maka kinerja perusahaan akan meningkan sehingga nilai saham juga meningkat, hal ini berdampak Net Asset Value (NAV) juga meningkat. (Huda dan Nasution, 2007:128).

Pengaruh Inflasi, Nilai Tukar Rupiah dan BI Rate Secara Simultan Terhadap Net Asset Value Reksa Dana Saham Syariah

Uji F digunakan untuk menunjukkan apakah semua variabel independen yang ada dalam penelitian mempunyai pengaruh secara bersama-sama terhadap variabel dependen. Dasar pengambilan keputusannya adalah dengan membandingkan nilai F-hitung dengan F-tabel dan nilai probabilitas (sig.). Apabila nilai F-hitung lebih besar dari nilai 
F-tabel (F-hitung>F-tabel), dan nilai probabilitas lebih kecil dari nilai $a=0,05$ (Sig <0,05), maka dapat disimpulkan bahwa terdapat pengaruh yang signifikan secara simultan antara variabel inflasi, nilai tukar rupiah dan Bl Rate terhadap net asset value reksa dana saham syariah. Hal ini berarti jika adanya peningkatan inflasi, nilai tukar rupiah dan BI Rate secara bersama-sama akan merubah net asset value reksa dana saham syariah, begitu pula sebaliknya.

Kita dapat melihat jika ketiga variabel diuji bersama sama maka ditemukan signifikansi terhadap net asset value reksa dana saham syariah, hal ini berarti masih ada celah yang dapat ditembus oleh ketiga variabel tersebut. Suatu pekerjaan besar ketika kita sebagai penggiat Ekonomi Syariah dapat membantu menambal hal dan kekurangan tersebut.

\section{SIMPULAN}

\section{Simpulan}

Berdasarkan hasil analisis dan pembahasan pada bab sebelumnya, maka dapat disimpulkan sebagai berikut :

1. Inflasi berpengaruh tidak signifikan terhadap net asset value reksa dana saham syariah.

2. Nilai Tukar Rupiah secara parsial berpengaruh signifikan terhadap net asset value reksa dana saham syariah dengan koefisien regresi sebesar $-0,131$ pada $a=5 \%$. Hal tersebut menunjukkan bahwa setiap kenaikan sebesar satu satuan pada Nilai Tukar Rupiah akan menurunkan net asset value reksa dana saham syariah sebesar 0,131 satuan.

3. BI Rate berpengaruh tidak signifikan terhadap net asset value reksa dana saham syariah.

4. Inflasi, Nilai Tukar Rupiah dan BI rate secara simultan berpengaruh signifikan terhadap net asset value reksa dana saham syariah, dengan persamaan regresi berganda :

Ynav $=12,081-1,755(I)-0,131$

(NTR) $-84,492$ (BI Rate)

\section{Saran}

Berdasarkan simpulan tersebut, saran yang disampaikan dalam penelitian ini adalah :

1. Untuk Manajer Investasi

Manajer investasi disarankan untuk tetap memperhatikan faktorfaktor ekonomi makro seperti inflasi, nilai tukar rupiah dan BI rate. Supaya dalam berinvestasi pada reksa dana saham syariah dapat memberikan konstribusi laba yang maksimal.

2. Untuk Masyarakat

Berdasarkan hasil penelitian ini disarankan kepada masyarakat jika hendak berinvestasi ke reksa dana saham syariah untuk tetap melihat faktor-faktor makro ekonomi seperti inflasi, nilai tukar rupiah dan $\mathrm{Bl}$ rate, agar dapat mengurangi resiko terjadinya 
kerugian dalam berinvestasi pada reksa dana saham syariah.

3. Untuk Penelitian Selanjutnya

Peneliti Selanjutnya dapat melanjutkan penelitian ini dengan obyek penelitian bukan dari net asset value reksa dana saham syariah tetapi bisa mengambil reksa dana syariah yang lain.

\section{DAFTAR PUSTAKA}

Agustina, Winda. 2011. Pengaruh Fluktuasi Jumlah Uang Beredar, Nilai Tukar Rupiah dan BI Rate Terhadap Nilai Aktiva Bersih per unit (NAB/unit) Reksadana Syariah. Jakarta: Skripsi, Fakultas Ekonomi dan Bisnis, Universitas Islam Negeri Syarif Hidayatullah.

Anshori, Muslich, dan Iswati, Sri. 2009. Buku Ajar Metodologi Penelitian Kuantitatif. Edisi Pertama, Surabaya : Airlangga University

Antonio, M. Syafi'i. 2001. Bank Syariah:Dari Teori ke Praktik. Jakarta:Gema Insani.

Arisandi, Tanto Dikdik. 2009. Analisis FaktorFaktor yang Mempengaruhi Perkembangan Reksadana Syariah di Indonesia. (Skripsi). Fakultas Ekonomi dan Manajemen Institut Pertanian Bogor.

Blanchard, Oliver. 2006. Macroeconomics Fourth Edition. New Jersey : Prentice Hall.

Brianto, Dimas. 2013. Analisis Pengaruh Suku Bunga Bank Indonesia Terhadap Reksa Dana Saham di Indonesia Tahun
2002-2012. Jakarta: Skripsi. Fakultas Ekonomi Bisnis, Universitas Islam Negeri Syarif Hidayatullah.

Elvira, Yuni, dan Fiteriyanto. NAB Reksadana Berlomba dengan Tingkat Suku Bunga. Jurnal Pasar Modal, No.06/VIII/Juni 1997.

Ghufron, Sofiyani, dkk. 2005. Investasi Halal di Reksa Dana Syariah, Jakarta : Renaisan.

Hifdzia, Rahmi. 2012. Pengaruh Variabel Makro Ekonomi Terhadap Perkembangan NAB Reksadana Syariah di Indonesia Tahun 2009-2011. Jakarta : Skripsi, Fakultas Ekonomi dan Bisnis, Universitas Islam Negeri Syarif Hidayatullah.

Huda, Nurul, dan Nasution, Mustafa Edwin. Nasution. 2007. Investasi pada Pasar Modal Syariah, Jakarta : Kencana.

Iskandar, Putong. 2002. Ekonomi Mikro dan Makro, Jakarta: Ghalia Indonesia.

Karl, E. Case, dan Fair, C. Rai. 2001. PrinsipPrinsip Ekonomi Makro. Jakarta: Prenhalindo.

Mankiw, Gregory. 2006. Pengantar Ekonomi Makro, Edisi Ketiga, Jakarta : Salemba Empat.

Nurlaili, Nunuk. 2012. Pengaruh Indeks Harga Saham Gabungan dan Rate bank Indonesia terhadap Nilai Aktiva Besih Reksadana Saham, Tesis Magister Manajemen. Universitas Terbuka.

Pasaribu, Rowland B. F., \& Dionysia Kowanda. 2014. Pengaruh Suku Bunga Sbi, Tingkat Inflasi, Ihsg, Dan Bursa Asing 
Terhadap Tingkat Pengembalian Reksa

Dana Saham, Jurnal Akuntansi \& Manajemen Vol. 25, No. 1, 53-65 Jakarta.

Pilbeam, Keith. 2006. International Finance 3rd Edition. New York.

Putratama, Hendra. 2007. Analisis FaktorFaktor yang Mempengaruhi Perkembangan Nilai Aktiva Bersih Reksadana Syariah di Indonesia. (Skripsi). Fakultas Ekonomi dan Manajemen Institut Pertanian Bogor.

Prasetyo, Bambang dan Lina, Miftahul Jannah. 2012. Metode Penelitian Kuantitatif, Jakarta: PT Raja Grafindo Persada

Rahmah, Layaly. 2011. Pengaruh Sertifikat Bank Indonesia Syariah (SBIS), Indeks Harga Saham Gabungan (IHSG) dan Nilai Tukar Rupiah terhadap Nilai Aktiva Bersih Danareksa Syariah Berimbang Periode Januari 2008 - Oktober 2010. (Skripsi). Jakarta : Universitas Islam Negri Syarif Hidayatullah.

Samuelson, Paul A. dan William D. Nordhaus, 2004. IImu Makroekonomi. Edisi Ketujuh Belas. Jakarta: PT. Gramedia Global Edukasi.

Sukirno, Sadono. 2006. Makroekonomi Teori Pengantar Edisi Ketiga, Jakarta : PT. Raja Grafindo Persada.

Sunariyah, 2004. Pengantar Pengetahuan Pasar Modal, edisi ke empat, Yogyakarta : UPP-AMP YKPN.

Susetyo, Kharisma. 2013. Analisa Pengaruh Inflasi Terhadap Kinerja Reksadana Saham di Indonesia Periode 2002-2012.
Jakarta: Skripsi, Fakultas Ekonomi dan Bisnis, Universitas Islam Negeri Syarif Hidayatullah.

Yusuf, Muhammad dan Wiroso. 2011 Bisnis Syariah, Jakarta : Penerbit Mitra Wacana Media. 